\title{
HOXA Gene Family
}

National Cancer Institute

\section{Source}

National Cancer Institute. HOXA Gene Family. NCI Thesaurus. Code C105821.

A family of genes found in a cluster on the $p$ arm of chromosome 7 . These genes

encode transcription factors that play a role in gene expression, morphogenesis, and cell differentiation. 